\title{
Antiproliferative Triterpenoid Saponins from Leptaulus citroides Baill. from the Madagascar Rain Forest
}

\author{
Qingxi Su $\cdot$ Peggy J. Brodie $\cdot$ Yixi Liu $\cdot$ \\ James S. Miller • Naina M. Andrianjafy • \\ Rabodo Antsiferana • Vincent E. Rasamison • \\ David G. I. Kingston (i)
}

Received: 12 October 2015/ Accepted: 19 December 2015/Published online: 8 January 2016

(C) The Author(s) 2016. This article is published with open access at Springerlink.com

\begin{abstract}
Bioassay-guided fractionation of EtOH extracts obtained from the roots and wood of the Madagascan plant Leptaulus citroides Baill. (Cardiopteridaceae) led to the isolation of ethyl esters of three new triterpenoid saponins (1-3) and the known sesquiterpenoid cinnamosmolide (4). The structures of 1-3 were elucidated by extensive 1D and 2D NMR experiments and mass spectrometry. Compounds 1, 2, and $\mathbf{4}$ showed moderate cytotoxicity against the A2780 human ovarian cancer cell line with $\mathrm{IC}_{50}$ values of $2.8,10.2$ and $2.0 \mu \mathrm{M}$, respectively.
\end{abstract}

Biodiversity Conservation and Drug Discovery in Madagascar, Part 67. For Part 66, see [1].

Electronic supplementary material The online version of this article (doi:10.1007/s13659-015-0083-1) contains supplementary material, which is available to authorized users.

Q. Su · P. J. Brodie · Y. Liu · D. G. I. Kingston ( $)$

Department of Chemistry, Virginia Tech Center for Drug

Discovery, M/C 0212, Virginia Tech, Blacksburg VA,

24061, USA

e-mail: dkingston@vt.edu

J. S. Miller

Missouri Botanical Garden, P.O. Box 299, St. Louis,

MO 63166-0299, USA

N. M. Andrianjafy

Missouri Botanical Garden, B.P 3391, 101 Antananarivo,

Madagascar

R. Antsiferana · V. E. Rasamison

Centre National d'Application des Recherches Pharmaceutiques,

B.P 702, 101 Antananarivo, Madagascar 


\section{Graphical Abstract}

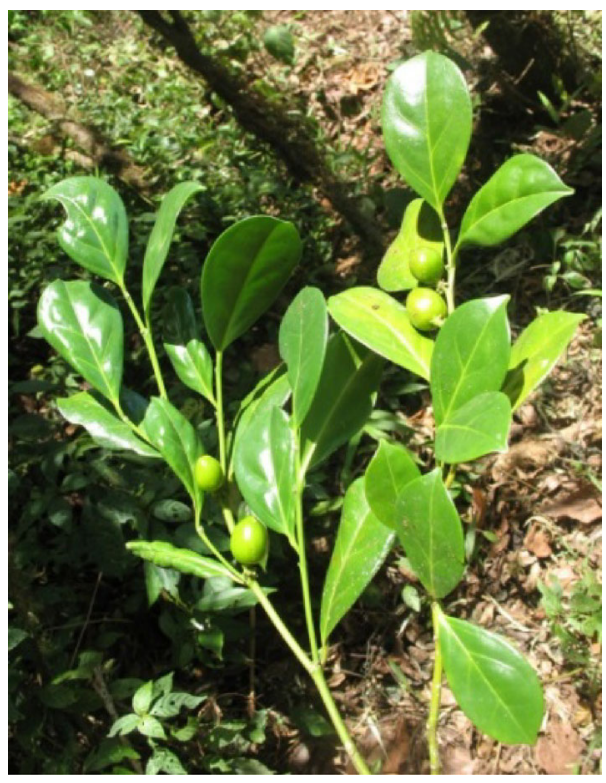

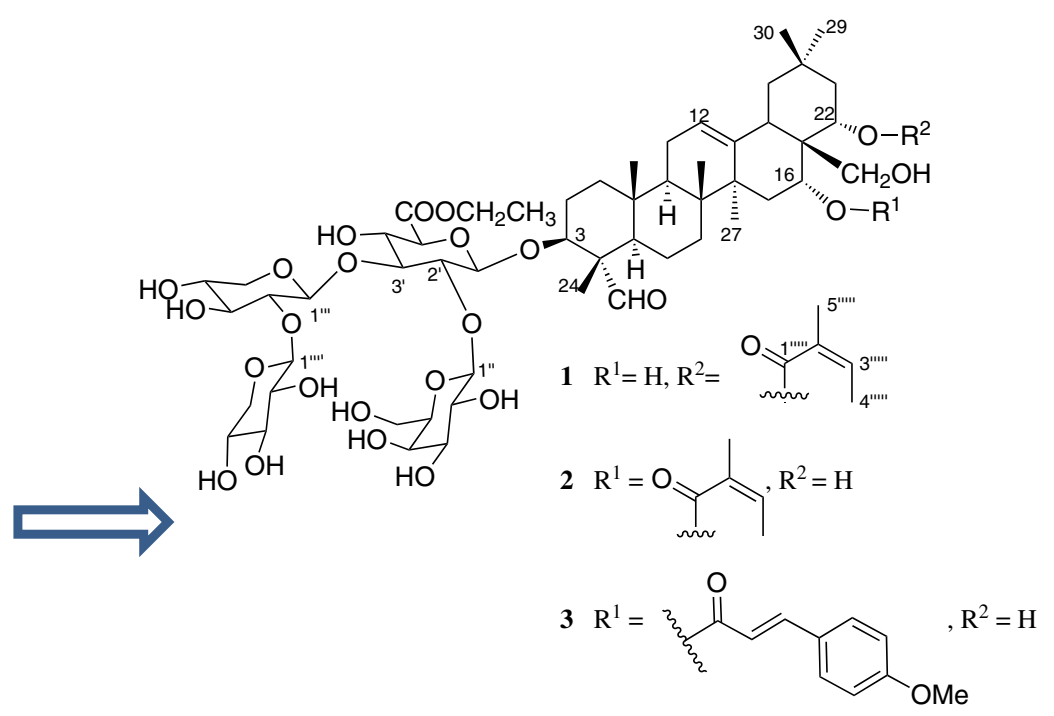

Antiproliferative Triterpenoid saponins isolated from Leptaulus citroides Baill.

Keywords Antiproliferative activity $\cdot$ Triterpenoid saponins $\cdot$ Leptaulus citroides (Cardiopteridacea)

\section{Introduction}

In our continuing search for bioactive natural products from Madagascar rainforests as part of the International Cooperative Biodiversity Group (ICBG) project, we have focused on the isolation of antiproliferative natural products from plant extracts collected from Madagascar forests $[2,3]$. As part of the research, we selected the EtOH extracts of the roots and wood of the plant Leptaulus citroides (Cardiopteridaceae) for investigation of antiproliferative natural products, since no previous chemical work has been reported on this genus. Bioassay-guided fractionation of the roots and wood extracts yielded ethyl esters of three new triterpenoid saponins (1-3) and the known sesquiterpenoid cinnamosmolide (4) [4]. Here we report the structure elucidation of compounds 1-3 and their antiproliferative activities.

\section{Results and Discussion}

Ethyl leptauloside A (1) was obtained as an amorphous white powder. Its HRESIMS revealed a sodiated quasimolecular ion peak at $m / z 1223.5806[\mathrm{M}+\mathrm{Na}]^{+}$, corresponding to the molecular formula $\mathrm{C}_{59} \mathrm{H}_{92} \mathrm{O}_{25}$. Compound 1 was assigned as an olean-12-ene triterpene derivative based on its 1D and 2D NMR spectra. The ${ }^{1} \mathrm{H}$ NMR spectrum of the aglycone part of compound $\mathbf{1}$ displayed characteristic signals of six singlet methyl groups $\left[\delta_{\mathrm{H}} 0.91\right.$, 0.95, 1.03, 1.05, 1.16 and 1.50, (each $3 \mathrm{H}$, all s, 29, 26, 25, $\left.\left.30,24,27-\mathrm{H}_{3}\right)\right]$, an olefin group $\left(\delta_{\mathrm{H}} 5.35, \mathrm{t}, J=3.5 \mathrm{~Hz}\right.$, $\mathrm{H}-12)$ and an aldehyde group $\left(\delta_{\mathrm{H}} 9.44, \mathrm{~s}\right)$. The position of the olefin group was confirmed by HMBC correlations of $\mathrm{H}_{3}-27\left(\delta_{\mathrm{H}} 1.50, \mathrm{~s}\right)$ to $\mathrm{C}-13\left(\delta_{\mathrm{C}} 144.1\right)$, and $\mathrm{H}-12$ to $\mathrm{C}-11$ $\left(\delta_{\mathrm{C}} 24.6\right)$ [5]. The aglycone moiety was oxygenated at $\mathrm{C}-3$, 16,22 , and 28 , based on the HMBC correlations between $\mathrm{H}_{3}-24\left(\delta_{\mathrm{H}} 1.16, \mathrm{~s}\right)$ and $\mathrm{C}-3\left(\delta_{\mathrm{C}} 86.3\right) ; \mathrm{H}-22 / \mathrm{H}_{3}-29 / \mathrm{H}_{3}-$ $30\left(\delta_{\mathrm{H}} 5.44, \mathrm{dd}, J=12.1,5.6 \mathrm{~Hz} / 0.91 \mathrm{~s} / 1.05 \mathrm{~s}\right)$ and $\mathrm{C}-21$ $\left(\delta_{\mathrm{C}} 42.1\right)$; between $\mathrm{H}-16 / \mathrm{H}-22\left(\delta_{\mathrm{H}} 4.11, \mathrm{brs} / \delta_{\mathrm{H}} 5.44\right.$, dd, $J=12.1,5.6 \mathrm{~Hz})$ and $\mathrm{C}-17\left(\delta_{\mathrm{C}} 45.3\right)$; and between $\mathrm{H}_{2}-28$ $\left(\delta_{\mathrm{H}} 3.05, \mathrm{~d}, J=10.9 \mathrm{~Hz} / 3.25 \mathrm{~m}\right)$ and $\mathrm{C}-22\left(\delta_{\mathrm{C}} 73.8\right)$. The aldehyde group $\left[\left(\delta_{\mathrm{H}} / \delta_{\mathrm{C}}\right): 9.44, \mathrm{~s} / 210.6\right]$ was located at $\mathrm{C}-4$ based on the HMBC correlation between the aldehyde proton and C-24 $\left(\delta_{\mathrm{C}} 10.8\right)$, in addition to comparison of $1 \mathrm{D}$ NMR data of 1 with previously reported data of similar compounds [6]. The 1D NMR and HSQC spectra of compound 1 showed the characteristic chemical shifts and coupling patterns of an angeloyl group, with one olefinic proton $\left[\delta_{\mathrm{H}} 6.07\left(1 \mathrm{H}, \mathrm{qq}, J=7.3,1.5 \mathrm{~Hz}, \mathrm{H}-3^{\prime \prime \prime \prime \prime}\right)\right]$, two methyl groups $\left[\delta_{\mathrm{H}} 1.98\left(3 \mathrm{H}, \mathrm{dq}, J=7.3,1.5 \mathrm{~Hz}, \mathrm{H}_{3}-4^{\prime \prime \prime \prime \prime \prime}\right)\right.$ and $1.90\left(3 \mathrm{H}, \mathrm{m}, \mathrm{H}_{3}-5^{\prime \prime \prime \prime \prime}\right)$ ], a carboxyl carbon $\left(\delta_{\mathrm{C}} 168.8\right.$, C- $\left.1^{\prime \prime \prime \prime \prime \prime}\right)$ and two $s p^{2}$ carbons $\left(\delta_{\mathrm{C}} 138.1\right.$ and 130.0, C- $3^{\prime \prime \prime \prime \prime \prime}$ and $\left.\mathrm{C}-2^{\prime \prime \prime \prime \prime \prime}\right)$, in agreement with the NMR data of related compounds [5-7]. The angeloyl group was assigned to 


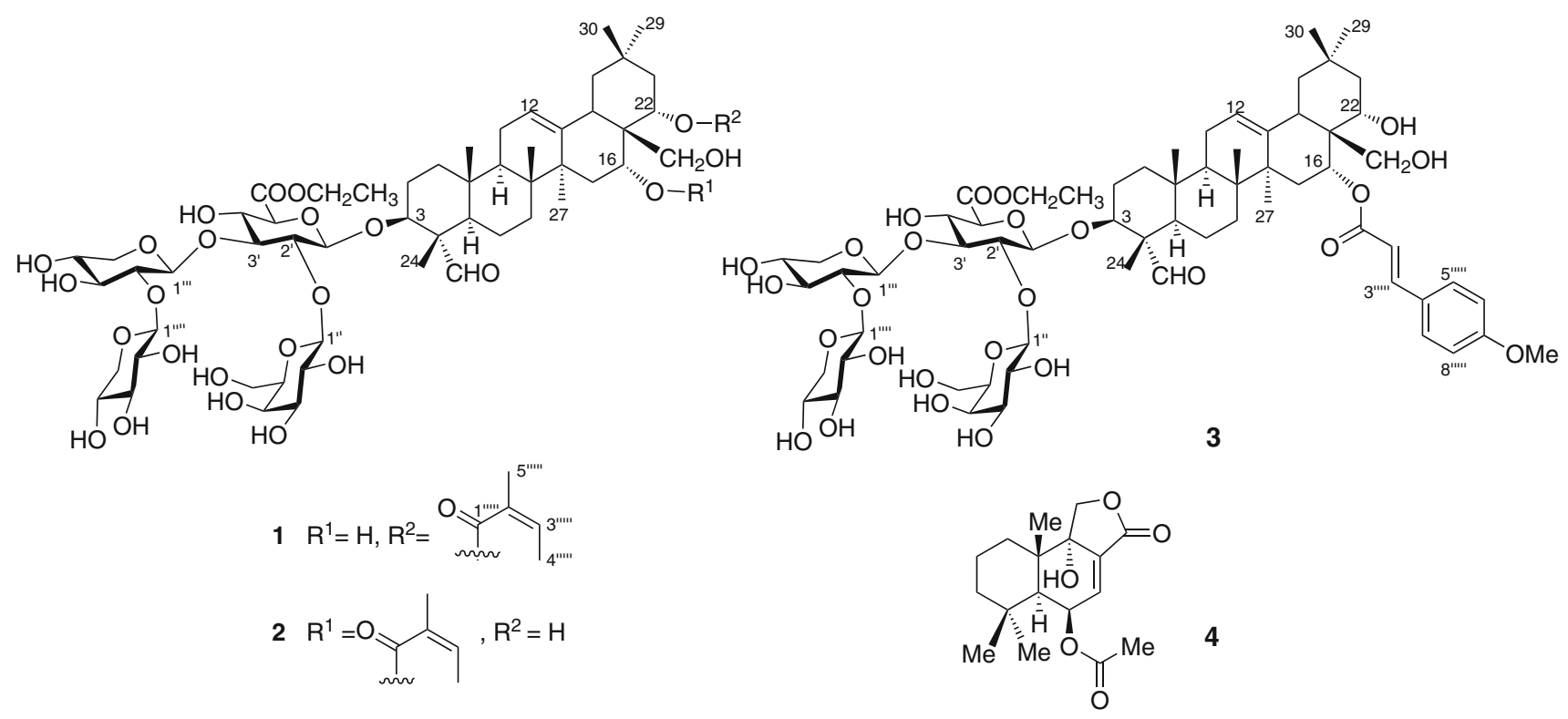

Fig. 1 Structures of compounds 1-4

C-22 based on the HMBC correlation between H-22 and the angeloyl carbonyl carbon. The spectroscopic data of the aglycone of $\mathbf{1}$ showed good agreement with the data of similar compounds reported previously [6-10]. The relative configurations of the aglycone and tetrasaccharide moiety were determined from coupling constants and ROESY correlations. The aldehyde group at C-4 was assigned the $\alpha$-equatorial orientation on the basis of ROESY correlations of $\mathrm{H}_{3}-24\left(\delta_{\mathrm{H}} 1.16, \mathrm{~s}\right)$ to the $\beta$-axially oriented $\mathrm{H}_{3}-25\left(\delta_{\mathrm{H}} 1.03, \mathrm{~s}\right)$ and of $\mathrm{H}-23\left(\delta_{\mathrm{H}} 9.44, \mathrm{~s}\right)$ to $\mathrm{H}-3$ $\left(\delta_{\mathrm{H}} 3.87, \mathrm{~m}\right)$ and $\mathrm{H}-5\left(\delta_{\mathrm{H}} 1.35, \mathrm{~m}\right)$, both of which were $\beta$ axial (Fig. 1). H-16 ( $\delta_{\mathrm{H}} 4.11$, brs) was assigned a $\beta$-equatorial orientation based on its appearance as a broad singlet, indicating small coupling constants, while $\mathrm{H}-22\left(\delta_{\mathrm{H}} 5.44\right.$, $\mathrm{dd}, J=12.3,5.6 \mathrm{~Hz}$ ) had the $\beta$-axial orientation based on its coupling constants; these assignments were confirmed by comparison with the chemical shifts and coupling constants of related protons of apodytines A-C [8]. The relative configurations of the aglycone were supported by comparison of its ${ }^{1} \mathrm{H}$ and ${ }^{13} \mathrm{C}$ NMR data with those of assamsaponin $\mathrm{A}[10]$ and camelliasaponin $\mathrm{B} 1$ [7].

The structure of the sugar moiety of $\mathbf{1}$ was elucidated on the bases of ${ }^{1} \mathrm{H}-{ }^{1} \mathrm{H} C O S Y$, TOCSY, ROESY, HSQC, and HMBC spectra. Four anomeric protons $\left[\delta_{\mathrm{H}} 4.97(1 \mathrm{H}, \mathrm{d}, J=7.2 \mathrm{~Hz})\right.$, $4.92(1 \mathrm{H}, \mathrm{d}, J=7.1 \mathrm{~Hz}), 4.51(1 \mathrm{H}, \mathrm{d}, J=7.6 \mathrm{~Hz})$ and 4.45 $(1 \mathrm{H}, \mathrm{d}, J=7.5 \mathrm{~Hz})]$ correlated with carbons at $\delta_{\mathrm{C}} 102.7$, $102.0,107.5$ and 104.8 were observed in the HSQC spectrum of $\mathbf{1}$, indicating the presence of four sugar units. The four sugar units were identified as $\beta$-glucuronopyranosyl (GlcA-1 $\left.1^{\prime}-6^{\prime}\right)$, $\beta$-galactopyranosyl (Gal-1"'-6"), $\beta$-xylopyranosyl (Xyl-1"' $\left.5^{\prime \prime \prime}\right)$, and $\beta$-xylopyranosyl (Xyl- $\left.1^{\prime \prime \prime \prime}-5^{\prime \prime \prime \prime}\right)$, by comparison of their ${ }^{13} \mathrm{C}$ NMR data with those of apodytine B [8], isotheasaponin $\mathrm{B}_{1}$ [11], and assamsaponin $\mathrm{A}[10]$. HMBC correlations of $\mathrm{H}-1^{\prime \prime}\left(\delta_{\mathrm{H}} 4.97, \mathrm{~d}\right)$ to $\mathrm{C}-2^{\prime}\left(\delta_{\mathrm{C}} 77.8\right), \mathrm{H}-1^{\prime \prime \prime}\left(\delta_{\mathrm{H}}\right.$ $4.92, \mathrm{~d})$ to $\mathrm{C}-3^{\prime}\left(\delta_{\mathrm{C}} 83.6\right)$, and $\mathrm{H}-1^{\prime \prime \prime \prime}\left(\delta_{\mathrm{H}} 4.51, \mathrm{~d}\right)$ to C-2 $2^{\prime \prime \prime}\left(\delta_{\mathrm{C}}\right.$ 85.1) indicated the connectivity of the four sugar units (Fig. 2). The HMBC correlation of $\mathrm{H}^{-1}{ }^{\prime}\left(\delta_{\mathrm{H}} 4.45\right.$, d, $J=7.5 \mathrm{~Hz})$ to $\mathrm{C}-3\left(\delta_{\mathrm{C}} 86.3\right)$, indicated that the tetrasaccharide moiety was connected to the aglycone at C-3. An ethyl ester group was present at $\mathrm{C}-5^{\prime}\left(\delta_{\mathrm{C}} 76.5\right)$ based on the COSY correlations of $\mathrm{H}_{2}-7^{\prime}\left(\delta_{\mathrm{H}} 4.22, \mathrm{q}, J=7.1 \mathrm{~Hz}\right)$ to $\mathrm{H}_{3}-8^{\prime}\left(\delta_{\mathrm{H}}\right.$ $1.28, \mathrm{t}, J=7.1 \mathrm{~Hz})$ and HMBC correlations of $\mathrm{H}_{2}-7^{\prime}\left(\delta_{\mathrm{H}}\right.$ 4.22, q, $J=7.1 \mathrm{~Hz})$ and $\mathrm{H}-5^{\prime}\left(\delta_{\mathrm{H}} 3.84, \mathrm{~d}, J=8.2 \mathrm{~Hz}\right)$ to a carboxyl carbon C-6 $6^{\prime}\left(\delta_{\mathrm{C}} 170.3\right)$. These facts led to the assignment of ethyl leptauloside A (1) as 3-O-\{ethyl [ $\beta$-D-galactopyranosyl- $(1 \rightarrow 2)][\beta$-D-xylopyranosyl- $(1 \rightarrow 2)$ $\beta$-D-xylopyranosyl- $(1 \rightarrow 3)]-\beta$-D-glucopyranosiduronate $\}$ $(3 \beta, 4 \alpha, 16 \alpha, 22 \alpha)-16,28$-dihydroxy-22-\{[(2Z)-2-methyl-1-oxo2-buten-1-yl]oxy \}-23-oxoolean-12-en-3-yl.

The structures and absolute configurations of the sugar moieties of 1 were confirmed by the method described by Tanaka and Kouno [12]. Compound 1 was subjected to acid hydrolysis and the resulting mixture was derivatized by treatment with L-cysteine methyl ester and $o$-tolylisothiocyanate. Comparison of the HPLC retention times of the resulting $o$-tolylthiocarbamoyl-thiazolidine derivatives of the sugar units with those of standards prepared from L-cysteine methyl ester and D and L-glucose, D and L-galactose, D and L-xylose, D and L-arabinose and D-glucuronic acid, and from D-cysteine methyl ester and D-glucuronic acid, confirmed the structures of the carbohydrate units as D-galactose, two D-xyloses, and D-glucuronic acid.

Ethyl esters of glucuronopyranosyl derivatives are unlikely to be natural products, so the ethyl ester was 


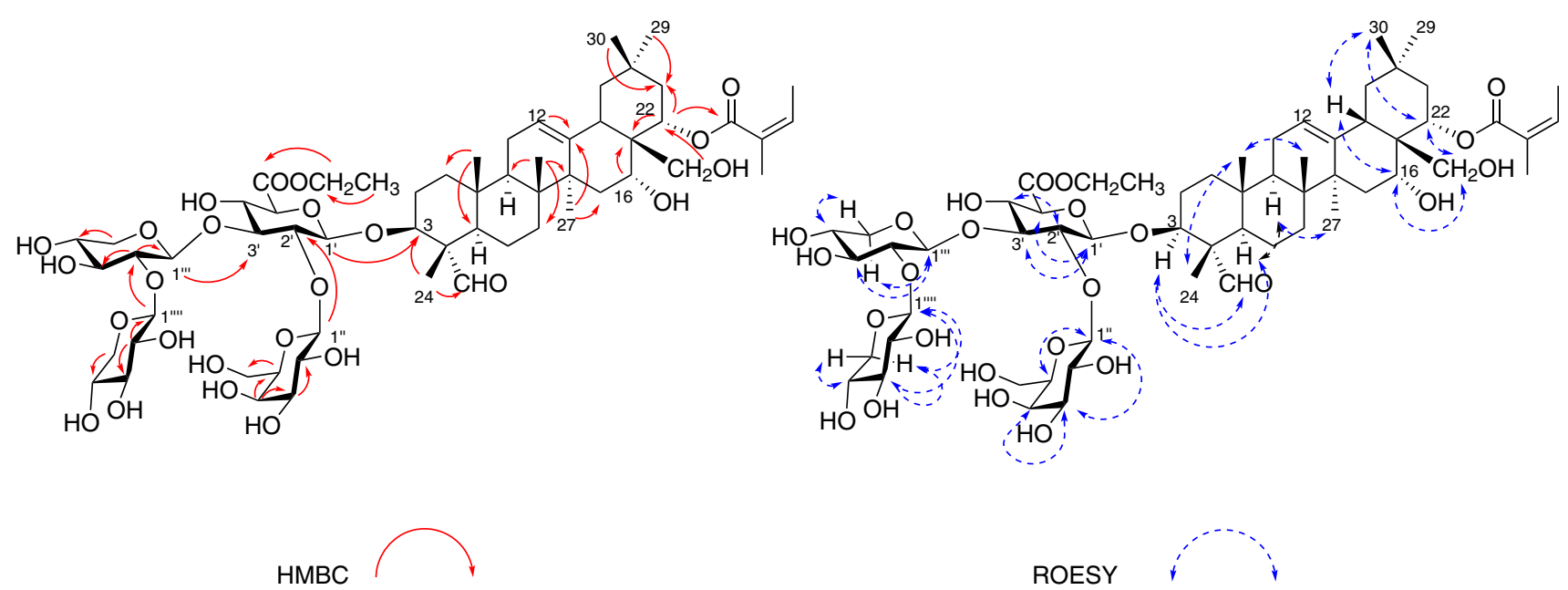

Fig. 2 Key HMBC (left) and ROESY (right) correlations of 1

probably formed as the plant material was extracted with $\mathrm{EtOH}$ and the solvent was evaporated. It was regrettably not feasible to collect fresh plant material and extract it with a different solvent to confirm this hypothesis.

Ethyl leptauloside B (2) was obtained as an amorphous white powder. The quasi-molecular ion peak at $\mathrm{m} / \mathrm{z}$ $1223.5781[\mathrm{M}+\mathrm{Na}]^{+}$corresponded to a molecular formula of $\mathrm{C}_{59} \mathrm{H}_{92} \mathrm{O}_{25}$. Further comparison of 1D NMR data of $\mathbf{2}$ suggested it is an isomer of $\mathbf{1}$ with the same sugar moiety and a similar aglycone to that of $\mathbf{1}$. The only difference between $\mathbf{1}$ and $\mathbf{2}$ was the position of the angeloyl and hydroxyl groups. The angeloyl group was assigned to C-16 in 2 , as indicated by the deshielded signal of $\mathrm{H}-16\left(\delta_{\mathrm{H}}\right.$ 5.63 , brs), and the hydroxyl group was assigned to C-22 due to the more shielded signal of $\mathrm{H}-22\left(\delta_{\mathrm{H}} 4.06\right.$, dd, $J=12.3,5.6 \mathrm{~Hz}$ ) compared to that of compound $\mathbf{1}[8,11]$. The aglycone of $\mathbf{2}$ was therefore elucidated as identical to that of theasaponin $G_{2}$ [13]. Compound 2 contained the same sugar moieties as $\mathbf{1}$ as shown by the essentially identical 1D NMR data of the two compounds. The structure of $\mathbf{2}$ was further confirmed by comparison of HSQC, HMBC and ROESY data with those of $\mathbf{1}$. Thus, the structure of ethyl leptauloside B (2) was determined as 3- $O$-\{ethyl [ $\beta$-D-galactopyranosyl- $(1 \rightarrow 2)][-\beta$-D-xylopyrano syl-( $1 \rightarrow 2)-\beta$-D-xylopyranosyl- $(1 \rightarrow 3)]-\beta$-D-glucopyranosi duronate $\}-(3 \beta, 4 \alpha, 16 \alpha, 22 \alpha)$-22,28-dihydroxy-16-\{[(2Z)-2methyl-1-oxo-2-buten-1-yl]oxy\}-23-oxoolean-12-en-3-yl (Fig. 1).

Ethyl leptauloside C (3) was obtained as an amorphous white powder. The quasi-molecular ion peak at $\mathrm{m} / \mathrm{z}$ $1301.5982[\mathrm{M}+\mathrm{Na}]^{+}$corresponded to a molecular formula of $\mathrm{C}_{64} \mathrm{H}_{94} \mathrm{O}_{26}$. Comparison of ${ }^{1} \mathrm{H}$ and ${ }^{13} \mathrm{C}$ NMR data with those of $\mathbf{2}$ indicated that they were closely related except that signals of the angeloyl group were replaced by those of a $p$-methoxycinnamoyl group in the spectra of $\mathbf{3}$. Thus the ${ }^{1} \mathrm{H}$ NMR spectrum of $\mathbf{3}$ showed signals of a para-substituted benzene ring at $\delta_{\mathrm{H}} 7.54(2 \mathrm{H}, \mathrm{d}, J=8.8 \mathrm{~Hz})$ and $6.98(2 \mathrm{H}, \mathrm{d}$, $J=8.8 \mathrm{~Hz}$ ), two olefinic protons with $E$ - configuration $\delta_{\mathrm{H}}$ $7.75(1 \mathrm{H}, \mathrm{d}, J=16.0 \mathrm{~Hz})$ and $\delta_{\mathrm{H}} 6.35(1 \mathrm{H}, \mathrm{d}, J=16.0 \mathrm{~Hz})$ and a methoxy group $\delta_{\mathrm{H}} 3.84(3 \mathrm{H}, \mathrm{s})$. These signals suggested the occurrence of a 4-methoxycinnamoyl group, and this was confirmed by HMBC correlations between the methoxy group $\left(\delta_{\mathrm{H}} 3.84, \mathrm{~s}, 3 \mathrm{H}\right)$ with $\mathrm{C} 7$, and $\mathrm{H}_{- \text {acyl-3 }}\left(\delta_{\mathrm{H}}\right.$ $7.75, \mathrm{~d}, J=16.0 \mathrm{~Hz})$ with $\mathrm{C}_{\text {-acyl-4 }}\left(\delta_{\mathrm{C}} 128.2\right)$. Comparisons of chemical shifts and coupling constants of $\mathrm{H}-16$ and $\mathrm{H}-22$ in $\mathbf{2}$ and $\mathbf{3}$ suggested the 4-methoxycinnamoyl group was attached to C-16 [8, 11]. Thus, the structure of ethyl leptauloside $\mathrm{C}(3)$ was determined as $3-O$ - $\{$ ethyl $[\beta$-D-galactopyranosyl- $(1 \rightarrow 2)][-\beta$-D-xylopyranosyl-( $(\rightarrow 2)-\beta$-D-xylo pyranosyl- $(1 \rightarrow 3)]-\beta$-D-glucopyranosiduronate $\}-(3 \beta, 4 \alpha$, $6 \alpha, 22 \alpha)$-22,28-dihydroxy-16-[(E-4-methoxycinnamoyl)oxy]23-oxoolean-12-en-3-yl (Fig. 1).

Compound $\mathbf{4}$ was isolated as a white solid. Its structure was assigned as shown based on comparison of its spectroscopic data with those reported in the literature [4]. Cinnamosmolide (4) has also been reported to display antifungal and $\alpha$-glucosidase inhibitory activities. $[14,15]$.

Compounds 1, 2, 3 and 4 were evaluated for antiproliferative activity against the A2780 human ovarian cancer cell line. Compounds $\mathbf{1}, \mathbf{2}$ and $\mathbf{4}$ showed $\mathrm{IC}_{50}$ values of 2.8 , 10.2 , and $2.0 \mu \mathrm{M}$ respectively, while compound 3 was inactive $\left(\mathrm{IC}_{50}>20 \mu \mathrm{g} / \mathrm{mL}\right.$, inhibiting $14 \%$ of cells growth at a concentration of $20 \mu \mathrm{g} / \mathrm{mL}$ ) in this assay. Previous studies suggested that acylation with angeloyl groups at C-21 and C-22 can affect the biological activities of oleanane triterpenoid saponins [5, 7, 16, 17]. These results support the importance of an angeloylated 22-hydroxyl group for antiproliferative activity. The reduced activity of compound $\mathbf{3}$ compared to $\mathbf{2}$ is possibly due to the bulkiness of the 4-coumaroyl group that acylates the C-16 hydroxyl group. 


\section{Conclusions}

Ethyl esters of the three new triterpenoid saponins leptaulosides A, B and C (1-3) and the known sesquiterpenoid cinnamosmolide (4) were isolated from Leptaulus citroides. Compounds 1, 2 and $\mathbf{4}$ showed moderate antiproliferative activity against the A2780 human ovarian cancer cell line in the A2780 assay. Ethyl leptauloside C (3) contained an aglycone moiety with an uncommon C-16 4-methoxycinnamate group; camelliagenin A cinnamate is one of the few examples of C-16 cinnamates of oleanane triterpenes [18].

\section{Experimental Section}

\subsection{General Experimental Procedures}

IR and UV spectra were measured on MIDAC M-series FTIR and Shimadzu UV-1201 spectrophotometers, respectively. 1D and 2D NMR spectra were recorded on a Bruker Avance 500 spectrometer in $\mathrm{CD}_{3} \mathrm{OD}$; chemical shifts are given in $\delta$ (ppm), and coupling constants are reported in Hz. Mass spectra were obtained on an Agilent 6220 LC-TOF-MS in the positive ion mode. Optical rotations were recorded on a JASCO P-2000 polarimeter. Open column chromatography was performed using Sephadex LH-20 and silica gel (40-63 $\mu \mathrm{m}$, Silicycle Co. USA). HPLC was performed on a Shimadzu LC-10AT instrument with a semipreparative C18 (Phenomenex Luna column, $5 \mu \mathrm{m}, 250 \mathrm{X} 10 \mathrm{~mm}$ ), a Shimadzu SPD M10A diode array detector, and a SCL-10A system controller. All isolated compounds were purified to $95 \%$ purity or better, as judged by HPLC (both UV and ELSD detection) before determining bioactivity.

\subsection{Antiproliferative Bioassays}

Antiproliferative activities were determined at Virginia Tech against the drug-sensitive A2780 human ovarian cancer cell line as previously described [19, 20].

\subsection{Plant Material}

Leptaulus citroides Baill. (Cardiopteridaceae) (vernacular name Tabonaka) were collected by N. M. Andrianjafy and coworkers at an elevation of about $600 \mathrm{~m}$ from a $10 \mathrm{~m}$ tall tree. Collection was made on a slope near the town of Ambodimangavalo in the district of Vavatenina, on the d'Ihofika river near the Andranofantsona camp, at coordinates $17^{\circ} 39^{\prime} 07^{\prime \prime} \mathrm{S} 048^{\circ} 58^{\prime} 14^{\prime \prime} \mathrm{E}$ (-17.6519400, 48.9705500). Dupl icate voucher specimens (Andrianjafy 323) were deposited at the Centre National d'Application des Recherches Pharmaceutiques (CNARP), the Herbarium of the Department of
Forestry and Fishery Research (TEF), and the Missouri Botanical Garden, St. Louis, Missouri (MO).

\subsection{Extraction and Isolation}

A ground sample of $L$. citroides bark (420 g) was extracted with $\mathrm{EtOH}(1000 \mathrm{~mL})$ at room temperature to yield $23.8 \mathrm{~g}$ of crude EtOH extract designated MG 1619, and a 5 g portion of this extract was made available to Virginia Tech for bioassay-guided isolation. Similar treatment of the wood $(412 \mathrm{~g})(1900 \mathrm{~mL})$ yielded $9.8 \mathrm{~g}$ of extract designated MG 1620 , and a $1.7 \mathrm{~g}$ portion of this extract was made available to Virginia Tech for bioassay-guided isolation.

\subsection{Isolation of Bioactive Constituents}

The EtOH extract of the root of $L$. citroides (MG 1619, $3 \mathrm{~g}$, $\mathrm{IC}_{50}=20 \mu \mathrm{g} / \mathrm{mL}$ ) was suspended in aqueous $\mathrm{MeOH}$ $\left(\mathrm{MeOH}-\mathrm{H}_{2} \mathrm{O}, 9: 1,100 \mathrm{~mL}\right)$ and extracted with hexane $(5 \times 100 \mathrm{~mL}$ portions). The aqueous fraction was then diluted to $60 \% \mathrm{MeOH}$ and further extracted with $\mathrm{CH}_{2} \mathrm{Cl}_{2}$ $\left(5 \times 100 \mathrm{~mL}\right.$ portions) to give a $\mathrm{CH}_{2} \mathrm{Cl}_{2}$ fraction $(477 \mathrm{mg})$ with an $\mathrm{IC}_{50}$ value of $11 \mu \mathrm{g} / \mathrm{mL}$. This fraction was further subjected to size exclusion open column chromatography on Sephadex LH-20 (I.D. $\times$ L $3 \times 50 \mathrm{~cm}$ ) eluted with 1:1 $\mathrm{CH}_{2} \mathrm{Cl}_{2}: \mathrm{MeOH}$ to yield four fractions, of which the most active fraction F3 (168 mg) exhibited an $\mathrm{IC}_{50}$ of $7.9 \mu \mathrm{g} / \mathrm{mL}$. Fraction F3 was applied to a silica gel column (I.D. $\times \mathrm{L}$ $3 \times 50 \mathrm{~cm}, 40-63 \mu \mathrm{m})$ and eluted with $\mathrm{CHCl}_{3}: \mathrm{MeOH}: \mathrm{H}_{2} \mathrm{O}$, 15:6:1 to give five fractions based on TLC profile. Fractions F3-3 (22.4 mg, $\left.\mathrm{IC}_{50}=2.5 \mu \mathrm{g} / \mathrm{mL}\right)$ and $\mathrm{F} 3-4(32.0 \mathrm{mg}$, $\mathrm{IC}_{50}=9.9 \mu \mathrm{g} / \mathrm{mL}$ ) were combined and further separated by HPLC on a semipreparative C18 column (Phenomenex Luna column, $5 \mu \mathrm{m}, 25 \times 1 \mathrm{~cm}$ ) with elution by a solvent gradient from $\mathrm{CH}_{3} \mathrm{OH}: \mathrm{H}_{2} \mathrm{O}, 50: 50$ to 60:40 from 0 to $10 \mathrm{~min}$, to 70:30 from 20 to $30 \mathrm{~min}$, to 100:0 from 30 to $35 \mathrm{~min}$, ending with $100 \% \mathrm{CH}_{3} \mathrm{OH}$ from 35 to $45 \mathrm{~min}$. This process gave crude compounds 1 (3.4 mg, $\mathrm{t}_{\mathrm{R}} 22 \mathrm{~min}$ ) and $2\left(3.0 \mathrm{mg}, \mathrm{t}_{\mathrm{R}} 23 \mathrm{~min}\right)$, and compound 3 (3.0 mg, $t_{R} 26 \mathrm{~min}$ ). Compounds 1 and 2 were each purified by HPLC on a semipreparative C18 column (Phenomenex Luna column, $5 \mu \mathrm{m}, 25 \times 1 \mathrm{~cm}$ ) eluted with a same solvent gradient from $\mathrm{CH}_{3} \mathrm{CN}: \mathrm{H}_{2} \mathrm{O}, 30: 70$ to 40:60 from 0 to $10 \mathrm{~min}$, to 50:50 from 10 to $40 \mathrm{~min}$, ending with $100 \% \mathrm{CH}_{3} \mathrm{CN}$ from 40 to $45 \mathrm{~min}$ to give purified compounds 1 ( $3.0 \mathrm{mg}, \mathrm{t}_{\mathrm{R}} 27 \mathrm{~min}$ ) and $2\left(2.8 \mathrm{mg}, \mathrm{t}_{\mathrm{R}} 40 \mathrm{~min}\right)$.

The EtOH extract of the wood of L. citroides (MG 1620, $1.5 \mathrm{~g}, \mathrm{IC}_{50}=20 \mu \mathrm{g} / \mathrm{mL}$ ) was subjected to liquid-liquid partition using same procedures described above. The active dichloromethane fraction ( $97 \mathrm{mg}, \mathrm{IC}_{50}=3.5 \mu \mathrm{g} / \mathrm{mL}$ ) was subjected to Sephadex LH-20 (I.D. $\times$ L $3 \times 50 \mathrm{~cm}$ ) chromatography to give four fractions. The active fraction $\mathrm{F}-4 \mathrm{~b}$ $\left(57.5 \mathrm{mg}, \mathrm{IC}_{50}=2.1 \mu \mathrm{g} / \mathrm{mL}\right)$ was then subjected to open silica gel column (I.D. $\times$ L $3 \times 50 \mathrm{~cm}, 40-63 \mu \mathrm{m}$ ) eluted 


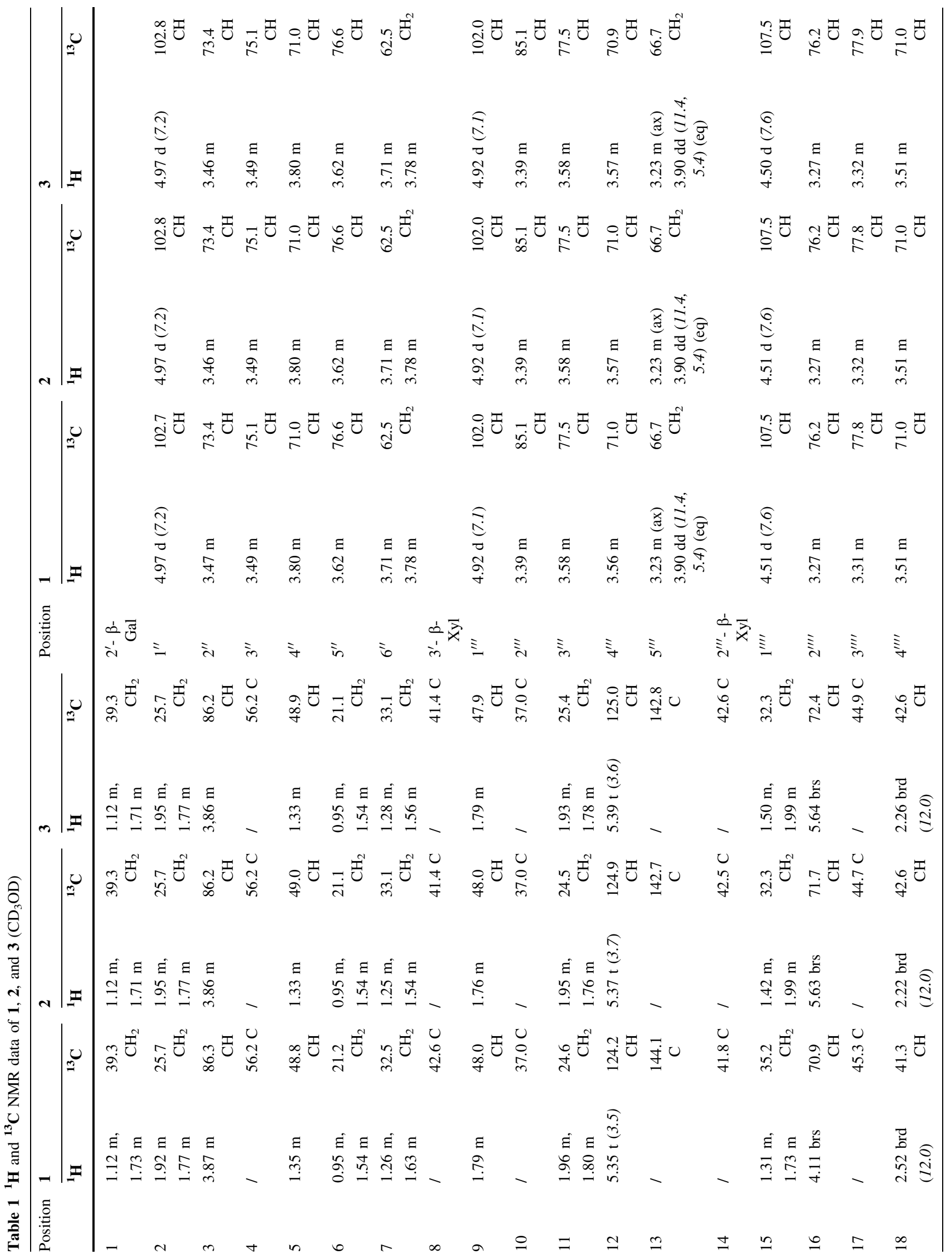




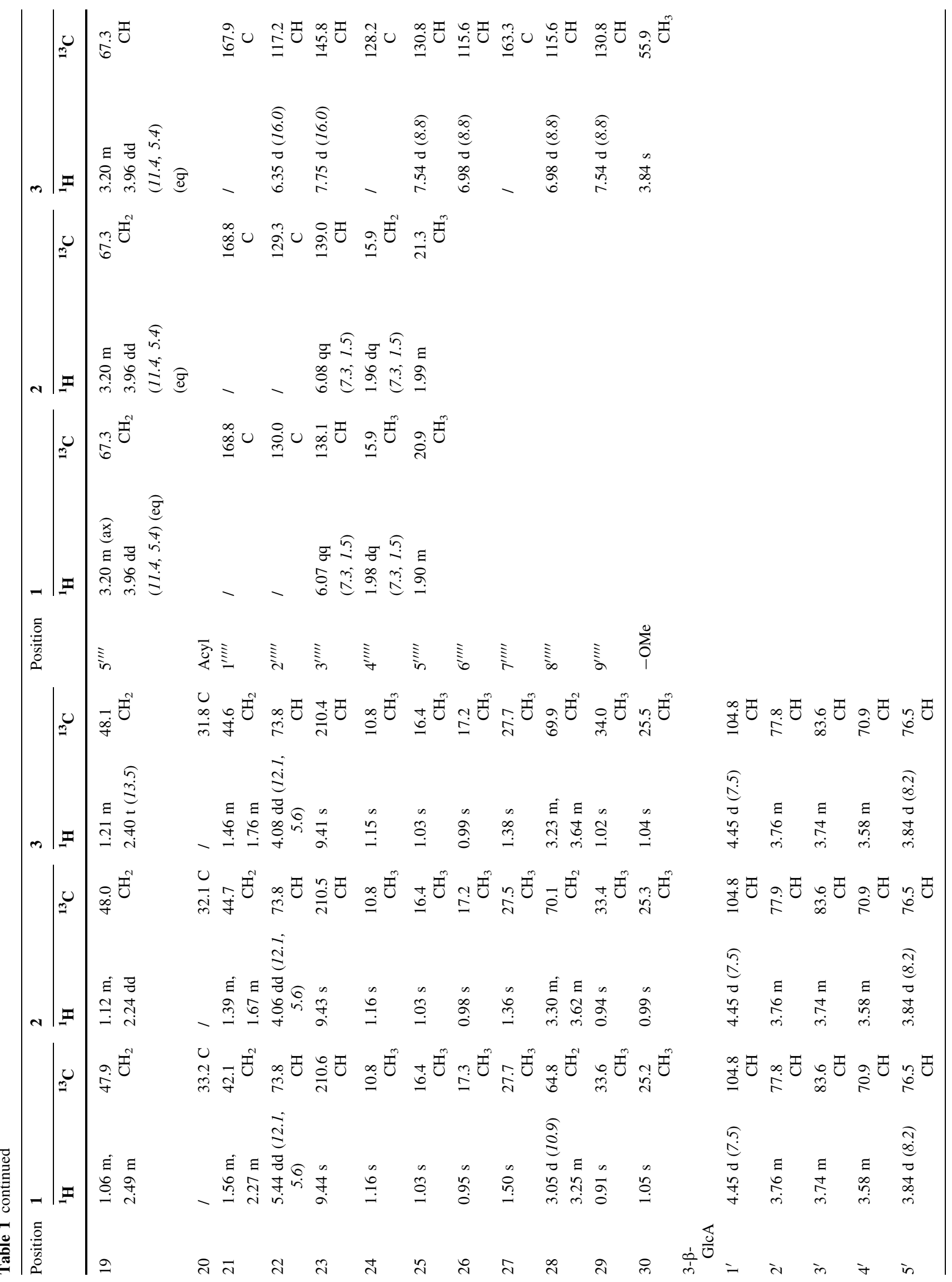




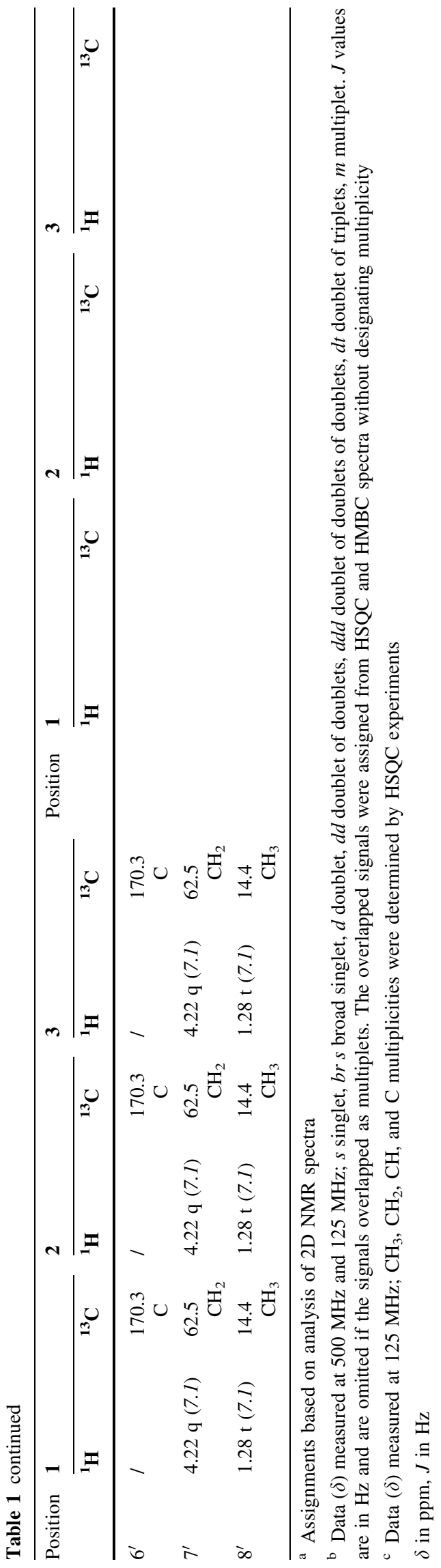

with $\mathrm{CHCl}_{3}-\mathrm{MeOH}, 20: 1$ to give four fractions. Fraction F-4b-2 $\left(29.2 \mathrm{mg}, \mathrm{IC}_{50}=1.4 \mu \mathrm{g} / \mathrm{mL}\right)$ was further separated by HPLC on a semipreparative C18 column (Phenomenex Luna column, $5 \mu \mathrm{m}, 25 \times 1 \mathrm{~cm}$ ) eluted by a solvent gradient from $\mathrm{CH}_{3} \mathrm{CN}: \mathrm{H}_{2} \mathrm{O}, 70: 30$ to $90: 10$ from 0 to $30 \mathrm{~min}$, to 100:0 from 30 to $40 \mathrm{~min}$, ending with $100 \% \mathrm{CH}_{3} \mathrm{CN}$ from 40 to $45 \mathrm{~min}$. This process gave compound $4\left(7.6 \mathrm{mg}, \mathrm{t}_{\mathrm{R}} 32 \mathrm{~min}\right)$.

4.6 Ethyl leptauloside A (1) 3-O-\{ethyl [ $\beta$-Dgalactopyranosyl- $(1 \rightarrow 2)][-\beta$-D-xylopyranosyl$(1 \rightarrow 2)$ - $\beta$-D-xylopyranosyl- $(1 \rightarrow 3)]-\beta$-Dglucopyranosiduronate $\}-(3 \beta, 4 \alpha, 16 \alpha, 22 \alpha)-16,28$ dihydroxy-22-\{[(2Z)-2-methyl-1-oxo-2-buten-1yl]oxy \}-23-oxoolean-12-en-3-yl

White powder; $[\alpha]_{\mathrm{D}}^{23}+3.0 \quad(c=0.19, \mathrm{MeOH}) ; \mathrm{UV}$ $(\mathrm{MeOH}) ; \lambda_{\max }(\log \varepsilon) 207$ (6.11) nm; IR (film) $v_{\max }$ 3350, 1773, 1613, 1521, 1158, $1078 \mathrm{~cm}^{-1} \cdot{ }^{1} \mathrm{H}-$ and ${ }^{13} \mathrm{C}-\mathrm{NMR}$ : see Table 1. HRESIMS $\mathrm{m} / \mathrm{z} 1223.5806[\mathrm{M}+\mathrm{Na}]^{+}$; $\mathrm{C}_{59} \mathrm{H}_{92} \mathrm{O}_{25} \mathrm{Na}^{+}$, (calc. 1223.5820).

4.7 Ethyl leptauloside B (2) 3- $O$-\{ethyl [ $\beta$-Dgalactopyranosyl- $(1 \rightarrow 2)][-\beta$-D-xylopyranosyl$(1 \rightarrow 2)$ - $\beta$-D-xylopyranosyl- $(1 \rightarrow 3)]-\beta$-Dglucopyranosiduronate $\}-(3 \beta, 4 \alpha, 16 \alpha, 22 \alpha)-22,28$ dihydroxy-16-\{[(2Z)-2-methyl-1-oxo-2-buten-1yl]oxy\}-23-oxoolean-12-en-3-yl

White powder; $[\alpha]_{D}^{23}-7.7(c=0.18, \mathrm{MeOH})$; UV $(\mathrm{MeOH})$ $\lambda_{\max }(\log \varepsilon) 209$ (6.11) nm; IR (film) $v_{\max }$ 3378, 1773, 1613, 1521, $1078 \mathrm{~cm}^{-1} .{ }^{1} \mathrm{H}-$ and ${ }^{13} \mathrm{C}-\mathrm{NMR}$ : see Table 1 . HRESIMS $m / z \quad 1223.5781[\mathrm{M}+\mathrm{Na}]^{+}, \mathrm{C}_{59} \mathrm{H}_{92} \mathrm{O}_{25} \mathrm{Na}^{+}$; (calc. 1223.5820).

4.8 Ethyl leptauloside C (3) 3-O-\{ethyl [ $\beta$-Dgalactopyranosyl-( $1 \rightarrow 2)][-\beta$-D-xylopyranosyl$(1 \rightarrow 2)$ - $\beta$-D-xylopyranosyl- $(1 \rightarrow 3)]-\beta$-Dglucopyranosiduronate $\}-(3 \beta, 4 \alpha, 16 \alpha, 22 \alpha)-22,28$ dihydroxy-16-[(E-4-methoxycinnamoyl)oxy $]-23-$ oxoolean-12-en-3-yl.

White Powder; $[\alpha]_{\mathrm{D}}^{23}+9.6(c=0.12, \mathrm{MeOH}) ; \mathrm{UV}(\mathrm{MeOH})$ $\lambda_{\max }(\log \varepsilon) 330$ (3.79), 282 (3.98), 225 (4.05), 209 (4.09) nm; IR (film) $v_{\max } 3386,1773,1609,1518,1175,1078,706 \mathrm{~cm}^{-1} .{ }^{1} \mathrm{H}-$ and ${ }^{13} \mathrm{C}$-NMR: see Table 1 . HRESIMS $\mathrm{m} / \mathrm{z} 1301.5982$ $[\mathrm{M}+\mathrm{Na}]^{+}, \mathrm{C}_{64} \mathrm{H}_{94} \mathrm{O}_{26} \mathrm{Na}^{+}$; (calc. 1301.5926).

4.9 Hydrolysis of Ethyl Leptauloside A (1) and Absolute Configurations of Its Carbohydrate Moieties.

Authentic methyl 2-(polyhydroxyalkyl)-3-(o-tolylthiocarbamoyl)-thiazolidine-4(R)-carboxylates were prepared from 
D- and L-galactose, D- and L-glucose, D- and L-xylose, D- and Lgalactose, D- and L-galactose, and D-glucuronic acid by reaction with L-cysteine methyl ester and $o$-tolylisothiocyanate as described [12]. Since L-glucuronic acid was not available, the enantiomeric (o-tolylthiocarbamoyl)-thiazolidine-4(S)-carboxylate of D-glucuronic acid was prepared by reaction with Dcysteine methyl ester and $o$-tolylisothiocyanate. Compound $\mathbf{1}$ $\left(2.0 \mathrm{mg}\right.$ ) was treated with $3 \mathrm{M} \mathrm{HCl}$ for $4 \mathrm{~h}$ at $100{ }^{\circ} \mathrm{C}$, and the solution was then neutralized with sodium bicarbonate and extracted thrice with EtOAc. The aqueous fraction was evaporated to dryness under reduced pressure. The resulting mixture of carbohydrates $(0.7 \mathrm{mg})$ was then dissolved in $0.5 \mathrm{~mL}$ pyridine, $0.9 \mathrm{mg}$ of L-cysteine methyl ester was added, and the mixture was heated at $60{ }^{\circ} \mathrm{C}$ for $1 \mathrm{~h}$. oTolylisothiocyanate $(0.9 \mathrm{mg})$ was then added to the mixture, which was again heated at $60{ }^{\circ} \mathrm{C}$ for $1 \mathrm{~h}$. The reaction mixture was directly analyzed by reverse-phase HPLC on a Phenomenex Luna column $(5 \mu \mathrm{m}, 25 \times 1 \mathrm{~cm})$, eluted with isocratic $0.1 \%$ formic acid in $\mathrm{CH}_{3} \mathrm{CN} / \mathrm{H}_{2} \mathrm{O}(15: 85)$ at a flow rate of $2.5 \mathrm{~mL} / \mathrm{min}$ for $5 \mathrm{~min}$, followed by $0.1 \%$ formic acid in $\mathrm{CH}_{3} \mathrm{CN} / \mathrm{H}_{2} \mathrm{O}$ (25:75) for $30 \mathrm{~min}$, and a wash with $100 \%$ $\mathrm{CH}_{3} \mathrm{CN}$ for $10 \mathrm{~min}$. The resulting chromatogram contained three major peaks with retention times of $25.29,29.12$, and $31.25 \mathrm{~min}$, identical to those of the derivatives of D-xylose, Dgalactose and D-glucuronic acid. Co-injection of each of the derivatives obtained by hydrolysis of $\mathbf{1}$ with its corresponding synthetic counterpart confirmed the identity of the compounds. The peak corresponding to the D-xylose derivative was approximately twice as large as that for the D-galactose derivative, consistent with the presence of two D-xylose units in $\mathbf{1}$.

Acknowledgments This project was supported by the Fogarty International Center, the National Cancer Institute, the National Institute of Allergy and Infectious Diseases, the National Institute of Mental Health, the National Institute on Drug Abuse, the National Heart Lung and Blood Institute, the National Center for Complementary and Alternative Medicine, the Office of Dietary Supplements, the National Institute of General Medical Sciences, the Biological Sciences Directorate of the National Science Foundation, and the Office of Biological and Environmental Research of the U.S. Department of Energy under Cooperative Agreement U01 TW00313 with the International Cooperative Biodiversity Groups. This project was also supported by the National Research Initiative of the Cooperative State Research, Education and Extension Service, USDA, Grant \#2008-35621-04732. These supports are gratefully acknowledged. Work at Virginia Tech was supported by the National Science Foundation under Grant CHE0722638 for the purchase of the Agilent 6220 mass spectrometer. We thank Mr. B. Bebout and Mr. Mehdi Ashraf-Khorassani for recording the mass spectra. Fieldwork essential for this project was conducted under a collaborative agreement between the Missouri Botanical Garden and the Parc Botanique et Zoologique de Tsimbazaza and a multilateral agreement between the ICBG partners, including the Centre National d'Application des Recherches Pharmaceutiques. We thank J. Razafitsalama, S. Randrianasolo, A. Rakotondrafara, L. Randrianjanaka, R. Mananjara, and C. Razanadrainy for assistance with plant collection, and we gratefully acknowledge courtesies extended by the Government of Madagascar (Ministère des Eaux et Forêts).
Compliance with Ethical Standards The botanical collection in Madagascar was carried out under a benefit-sharing agreement between all the parties involved, and under the authority of plant collection and extract export permits issued by the government of Madagascar.

Conflict of Interest The authors declare no conflict of interest.

Open Access This article is distributed under the terms of the Creative Commons Attribution 4.0 International License (http:// creativecommons.org/licenses/by/4.0/), which permits unrestricted use, distribution, and reproduction in any medium, provided you give appropriate credit to the original author(s) and the source, provide a link to the Creative Commons license, and indicate if changes were made.

\section{References}

1. Y. Liu, C.H. Wiedle, P.J. Brodie, M.W. Callmander, R. Rakotondrajaona, E. Rakotobe, V.E. Rasamison. D.G.I. Kingston, Nat. Prod. Commun. 10, 1509-1512 (2015)

2. D.G.I. Kingston, J. Nat. Prod. 74, 496-511 (2010)

3. Y. Liu, L.H. Rakotondraibe, P.J. Brodie, J.D. Wiley, M.B. Cassera, J.S. Miller, F. Ratovoson, E. Rakotobe, V.E. Rasamison, D.G.I. Kingston, J. Nat. Prod. 78, 1330-1338 (2015)

4. I.I. Mahmoud, A.D. Kinghorn, G.A. Cordell, N.R. Farnsworth, J. Nat. Prod. 43, 365-371 (1980)

5. S. Cao, P. Brodie, M. Callmander, R. Randrianaivo, J. Razafitsalama, E. Rakotobe, V.E. Rasamison, K. TenDyke, Y. Shen, E.M. Suh, J. Nat. Prod. 72, 1705-1707 (2009)

6. M. Yoshikawa, T. Morikawa, N. Li, A. Nagatomo, X. Li, H. Matsuda, Chem. Pharm. Bull. 53, 1559-1564 (2005)

7. M. Yoshikawa, E. Harada, T. Murakami, H. Matsuda, J. Yamahara, N. Murakami, Chem. Pharm. Bull. 42, 742-744 (1994)

8. K. Foubert, F. Cuyckens, A. Matheeussen, A. Vlietinck, S. Apers, L. Maes, L. Pieters, Phytochemistry 72, 1414-1423 (2011)

9. T. Morikawa, N. Li, A. Nagatomo, H. Matsuda, X. Li, M. Yoshikawa, J. Nat. Prod. 69, 185-190 (2006)

10. T. Murakami, J. Nakamura, H. Matsuda, M. Yoshikawa, Chem. Pharm. Bull. 47, 1759-1764 (1999)

11. K. Kobayashi, T. Teruya, K. Suenaga, Y. Matsui, H. Masuda, H. Kigoshi, Phytochemistry 67, 1385-1389 (2006)

12. T. Tanaka, T. Nakashima, T. Ueda, K. Tomii, I. Kuono, Chem. Pharm. Bull. 55, 899-901 (2007)

13. T. Morikawa, H. Matsuda, N. Li, S. Nakamura, X. Li, M. Yoshikawa, Heterocycles 68, 1139-1148 (2006)

14. V.T. Amiguet, P. Petit, C.A. Ta, R. Nuñez, P. Sánchez-Vindas, L.P. Alvarez, M.L. Smith, J.T. Arnason, T. Durst, J. Nat. Prod. 69, 1005-1009 (2006)

15. L. Harinantenaina, K. Matsunami, H. Otsuka, M. Kawahata, K. Yamaguchi, Y. Asakawa, J. Nat. Prod. 71, 123-126 (2008)

16. P.K. Chan, Biochem. Pharmacol. 73, 341-350 (2007)

17. T. Ikeda, S. Fujiwara, K. Araki, J. Kinjo, T. Nohara, T. Miyoshi, J. Nat. Prod. 60, 102-107 (1997)

18. T. Ogino, T. Hayasaka, S. Ito, T. Takahashi, Chem. Pharm. Bull. 16, 1846-1847 (1968)

19. S. Cao, P.J. Brodie, J.S. Miller, R. Randrianaivo, F. Ratovoson, C. Birkinshaw, R. Andriantsiferana, V.E. Rasamison, D.G.I. Kingston, J. Nat. Prod. 70, 679-681 (2007)

20. E. Pan, L. Harinantenaina, P.J. Brodie, J.S. Miller, M.W. Callmander, S. Rakotonandrasana, E. Rakotobe, V.E. Rasamison, D.G.I. Kingston, J. Nat. Prod. 73, 1792-1795 (2010) 